\title{
Some Challenges of International Litigation
}

\author{
HE Judge Sir Christopher Greenwood CMG QC*
}

\section{Keywords}

International litigation, International Court of Justice

\section{Introduction}

I first studied international law 35 years ago. As a candidate for what was then Section D of the LL.B. (the public international law papers) at Cambridge, I attended lectures and seminars on the International Court of Justice (ICJ) and on international, that is inter-state, arbitration. It was a wonderful time to be a student of these subjects, not least because we were studying case law when there were comparatively few cases to study, which left plenty of scope for the enjoyment of other aspects of student life. The ICJ, whose reports for 1977 are only four pages long, had only one case pending before it (over which it would soon decide that it lacked jurisdiction). ${ }^{1}$ The European Court of Human Rights (ECtHR) was then the only functioning human rights court and its entire jurisprudence could still fit into a single volume of law reports, although the European Commission of Human Rights, to which at that time all applications had to be made, had decided many more cases. Investor-state arbitration was largely unknown. There were no international criminal courts or tribunals and almost no serious discussion of the possibility of creating such bodies.

Moreover, it would be difficult to argue that the proceedings which did take place at that time occupied a central place in international relations. Although some of the judgments given by the ICJ during the 1970s were to have an important effect on the development of the law, they had less obvious impact at the time. Between 1971 and 1980 only nine contentious cases were brought before the Court. One of those was withdrawn ${ }^{2}$ and one was still pending at

\footnotetext{
Judge, International Court of Justice.

1 Aegean Sea Continental Shelf (Greece v Turkey), Judgment, ICJ Reports 1978, p. 3.

2 Trial of Pakistani Prisoners of War (Pakistan v India), Interim Protection, Order of 13 July 1973, ICJ Reports 1973, p. 328. An Order officially recording the discontinuance of the proceedings was issued on 15 December 1973.
} 
the end of the decade. ${ }^{3}$ In six of the remaining seven cases, the respondent state boycotted all or part of the proceedings. ${ }^{4}$

Yet the ICJ underwent a revival in the 1980s and 1990s, years which also saw a remarkable increase in the number and variety of international courts and tribunals and the matters being brought before them. The result was to propel litigation into a far more prominent place in international relations than it had ever occupied before. Even in matters as fundamental as war and peace, for many states the prospect of having to defend their decisions before a court is now a reality which it would be dangerous to ignore. One example must suffice. In 1982 the United Kingdom and Argentina fought an armed conflict over the Falkland Islands which left several hundred dead. The record shows that the United Kingdom government took legal advice throughout the conflict but, so far as I have been able to discover, neither government's actions were challenged before a court with the exception of a case that went to the Supreme Court of the United States about the inexplicable sinking of a US-owned merchant ship by Argentina many hundreds of miles away from the islands. ${ }^{5}$ By contrast, the Kosovo conflict, in which United Kingdom forces were involved less than twenty years later, saw the Federal Republic of Yugoslavia (FRY) challenge ten NATO states before the ICJ while the hostilities were still going on ${ }^{6}$ and

3 Continental Shelf (Tunisia/Libyan Arab Jamahiriya), Judgment, ICJ Reports 1982, p. 18. The case was commenced by special agreement between the parties and entered on the Court's General List in 1978.

4 The Appeal Relating to the Jurisdiction of the ICAO Council (India v Pakistan), Judgment, ICJ Reports 1972, p. 46 was the only case to be commenced and brought to a decision during the decade in which the Respondent took a full part in the proceedings. The Respondent boycotted the proceedings from the outset in Fisheries Jurisdiction (United Kingdom v Iceland), Merits, Judgment, ICJ Reports 1974, p. 3; Fisheries Jurisdiction (Federal Republic of Germany $v$ Iceland), Merits, Judgment, ICJ Reports 1974, p. 175; Nuclear Tests (Australia v France), Judgment, ICJ Reports 1974, p. 253 and Nuclear Tests (New Zealand v France), Judgment, ICJ Reports 1974, p. 457; Aegean Sea Continental Shelf, supra note 1; and United States Diplomatic and Consular Staff in Tehran (United States of America v Iran), Judgment, ICJ Reports 1980, p. 3.

${ }^{5}$ Argentine Republic v Amerada Hess Shipping Corp., 488 US 428 (1989); 81 ILR 658. Another case was brought unsuccessfully before the ECtHR many years later. On 19 July 2000, the Court declared inadmissible an application from the parents of two men killed when British forces torpedoed and sank the Argentinean warship the General Belgrano. The applicants alleged that the ship's sinking was a violation of their sons' rights to life under Article 2 of the 1950 Convention for the Protection of Human Rights and Fundamental Freedoms, 213 UNTS 221. The application was declared inadmissible by a Committee of three judges for having been submitted well beyond the six month time limit stipulated in the Convention: Luisa Diamantina Romero de Ibanez and Roberto Guillermo Rojas v United Kingdom, Admissibility Decision of 19 July 2000 (Application No. 58692/00).

${ }^{6}$ See, e.g., Legality of Use of Force (Yugoslavia v Belgium), Provisional Measures, Order of 2 June 
the Grand Chamber of the ECtHR deliver a landmark decision regarding the air attack on the Radio Television Serbia studios in Belgrade. ${ }^{7}$ The conflict featured in the charges against several of the defendants brought before the International Criminal Tribunal for the Former Yugoslavia (ICTY), including the former President of the FRY, Slobodan Milosevic. The Prosecutor of the ICTY also conducted an investigation into whether there was a case for bringing charges against any NATO personnel.

It will come as no surprise that international lawyers have generally reacted with pleasure and sometimes delight to these developments. As the late Oscar Schachter once told the ICJ, "to a shoemaker there is nothing like leather, to a lawyer there is nothing like a court". That sense of delight-which I share-is understandable. Even if we now regard some of the idealistic thinking about international adjudication which characterised much of "civil society" at the time of the Hague Peace Conferences in 1899 and 1907 as overstated, there is no doubt that the effective and impartial adjudication of international disputes makes the world a safer place and one in which justice plays a greater role. Moreover, it is not simply the disputes which come before a court which are affected by the judgments which that court gives. The clear and coherent articulation of legal principles on, for example, the delimitation of maritime boundaries, and the availability of fora in which those principles can be applied, also facilitate the settlement of disputed boundaries by negotiation. Moreover, the new prominence of courts and tribunals in which individuals and other non-state entities can vindicate their rights against states-for example, in human rights courts or investor-state arbitration-has made those rights a reality in many cases where they would otherwise have had only a paper existence.

Nevertheless, this new world of adjudication has also created challenges, the existence of which is all too often overlooked. My purpose today is to look at some of the challenges of international litigation. In doing so, I have taken a broad view of what constitutes litigation. I include not only litigation

1999, ICJ Reports 1999, p. 124. The requests for provisional measures were rejected. The cases against Spain and the USA were removed from the Court's List in 1999 for manifest absence of jurisdiction. The Court decided in 2004 that it lacked jurisdiction regarding the remaining eight cases: see, e.g., Legality of Use of Force (Serbia and Montenegro v Belgium), Preliminary Objections, Judgment, ICJ Reports 2004, p. 279.

7 Bankovic v Belgium, Admissibility Decision of 12 December 2001, 123 ILR 94.

8 Questions of Interpretation and Application of the 1971 Montreal Convention arising from the Aerial Incident at Lockerbie (Libyan Arab Jamahiriya $v$ United States of America); hearings, 15 October 1997; CR 1997/19, at 31. 
between states but also litigation in which a state is challenged by an individual or corporation, as in cases before a human rights court or in investor-state arbitrations at the International Centre for Settlement of Investment Disputes (ICSID) or elsewhere. I have also included proceedings before international criminal courts and tribunals. Although criminal proceedings are not strictly "litigation", international criminal proceedings share enough of the features of other proceedings before international courts that it would be wrong to exclude them. I have, however, confined myself to litigation before international courts and tribunals, whether global or regional, and have not attempted here to explore the equally important subject of the litigation of international law issues before national courts; that must be the subject of a future paper. ${ }^{9}$

\section{The growth of international litigation}

First, however, let us get a sense of perspective. To do that, I need to demonstrate the extent to which international litigation has grown over the last 35 years. It makes sense to start with the ICJ, which is the only court that is both global (in the sense that any of the 193 member states of the UN may participate in its activities) and general (in that its jurisdiction potentially covers any aspect of international law). From the low point of 1977 with one pending case and an empty volume of law reports, the Court has been revitalised, and in recent years has never had fewer than 12 cases on its List. ${ }^{10}$ Those cases come from all parts of the world. In the last few years, the Court has ruled on disputes involving states from every inhabited continent. The cases also cover a wide spectrum of issues.

${ }_{9}$ On the litigation of international law issues before domestic courts, see Shaw's excellent lectures as part of the Hersch Lauterpacht Memorial Lectures Series, 'Regulating the Relationship between International and Domestic Law' (Part One: 2 March 2010; Part Two: 3 March 2010; Part 3: 4 March 2010). On the interaction of European Union law and international law, see van Rossem, 'Interaction Between EU Law and International Law in Light of Intertanko and Kadi: The Dilemma of Norms Binding the Member States but not the Community', (2009) 40 Netherlands Yearbook of International Law 183.

${ }^{10}$ At the time this paper was originally delivered, the Court had fifteen cases before it. Since then, the delivery of a judgment in Jurisdictional Immunities of the State (Germany $v$ Italy: Greece intervening), 3 February 2012 (not yet published), available at $<\mathrm{http}$ ://www.icjcij.org/docket/files/143/16883.pdf> [last accessed 15 May 2012], and an advisory opinion in Judgment No. 2867 of the Administrative Tribunal of the International Labour Organization upon a Complaint Filed against the International Fund for Agricultural Development (Request for Advisory Opinion), 1 February 2012 (not yet published), available at <http://www.icjcij.org/docket/files/146/16871.pdf> [last accessed 15 May 2012], has reduced the List to thirteen. 
During my first three years as a judge, the Court considered cases involving river navigation, pollution, sovereign immunity, the prosecution of a former head of state, land and maritime boundaries, a declaration of independence, diplomatic protection, armed conflict and a dispute between two neighbours over one's opposition to the other's choice of name. More new cases were filed in 2008 alone than in the decade from 1961-1970. Participation in the activities of the Court has also been more widespread than is sometimes realised. 88 states have at some time been party to a contentious case before the Court and, in 2009, 43 states took part in one way or another in the proceedings on the General Assembly's request for an advisory opinion on Kosovo's declaration of independence.

One aspect of this growth in the work of the ICJ which should not go unremarked is that it has not been at the expense of other methods of inter-state dispute settlement. When the UN Convention on the Law of the Sea ${ }^{11}$ was concluded in 1982, its elaborate provisions on dispute settlement led to gloomy predictions that either the newly created International Tribunal for the Law of the Sea (ITLOS) and arbitration tribunals operating under Annex VII would bring about the end of maritime boundary delimitation work in the ICJ, or they would themselves be left without work. That has not happened. While maritime boundary work in the ICJ has increased, ${ }^{12}$ in recent years there have also been a number of Annex VII arbitrations ${ }^{13}$ and ITLOS, long busy with other types of case, has recently delivered its first delimitation judgment. ${ }^{14}$

The growth in international litigation has, however, been even more conspicuous in four other areas. First, investor-state arbitration, which barely existed 35 years ago ${ }^{15}$ (even though the Washington Convention ${ }^{16}$ which created

${ }^{11} 1982$ United Nations Convention on the Law of the Sea, 1833 UNTS 3.

${ }^{12}$ See, most recently, the judgments in Territorial and Maritime Dispute between Nicaragua and Honduras in the Caribbean Sea (Nicaragua v Honduras), Judgment, ICJ Reports 2007, p. 659 and Maritime Delimitation in the Black Sea (Romania v Ukraine), Judgment, ICJ Reports 2009, p. 61. At the time of writing, the Court had two further maritime boundary cases on its General List, Territorial and Maritime Dispute (Nicaragua v Colombia) and Maritime Dispute (Peru v Chile).

${ }^{13}$ Barbados v Trinidad and Tobago, (2006) 139 ILR 449; Guyana v Suriname, (2007) 139 ILR 566. See also the pending case of Bangladesh $v$ India (Permanent Court of Arbitration).

${ }^{14}$ Dispute concerning delimitation of the maritime boundary between Bangladesh and Myanmar in the Bay of Bengal (Bangladesh/Myanmar), Judgment of 14 March 2012 (not yet published), available at <http://www.itlos.org/fileadmin/itlos/documents/cases/case_no_16/1-C16_Judgment_14 _02_2012.pdf> [last accessed 15 May].

${ }^{15}$ See, however, the three Libyan oil arbitrations decided between 1973 and 1980; Greenwood, 'State Contracts in International Law: The Libyan Oil Arbitrations', (1982) 53 BYIL 27.

${ }^{16} 1965$ Convention on the settlement of investment disputes between states and nationals of other states, 575 UNTS 159. 
ICSID had been in force for a decade) has acquired enormous importance since the mid-1990s. Between 1972 and the end of 2011, ICSID registered 369 cases, of which 334 were registered since 1995. 2011 saw the largest number of new cases (38) registered by ICSID.$^{17}$ Although there are no centrally compiled statistics, it is generally believed that at least as many investor-state arbitrations have been decided by non-ICSID tribunals during the years since 1995. Mention must also be made of the Iran-US Claims Tribunal which has finalised nearly 4,000 cases since it was established in 1981.

Secondly, there has been the emergence of international criminal courts and tribunals. I should, perhaps, say the re-emergence, for the tribunals which tried the major war criminals at Nuremberg and Tokyo had (at least in some respects) an international character, but each was assembled for a single case and then dissolved. It was not until 45 years later, when the ICTY was established by the Security Council, that criminal cases were again heard by an international tribunal, as opposed to a body deriving its legal authority from national law. I confess to having been sceptical about the prospects for the ICTY in 1993. I thought at the time that there was a serious risk that the Tribunal would try hardly any cases and be perceived as a failure which would have had the effect of setting back the prospects for international criminal law. I am pleased to have been proved wrong-or at least to have been too pessimistic, for I still believe that the risk existed and it is a remarkable achievement that it was overcome. After nearly twenty years, the ICTY has tried over 160 defendants and all of the leading suspects indicted by it have been taken into custody. It has been joined by the International Criminal Tribunal for Rwanda, the Special Court for Sierra Leone, the Tribunal for Lebanon and, of course, the International Criminal Court (ICC). The ICC, established by the 1998 Rome Statute ${ }^{18}$ handed down its first verdict a few days before this paper went to press. ${ }^{19}$ All of these courts and tribunals have cases pending before them.

Thirdly, the dispute settlement mechanism of the World Trade Organization is the most prolific of the international dispute settlement systems, with some 419 requests lodged in its first 15 years of operation between 1995 and 2010. Almost 200 of these have proceeded through to completion or settlement. ${ }^{20}$ With a far higher profile than its predecessor under the GATT, the

\footnotetext{
${ }^{17}$ ICSID, The ICSID Caseload-Statistics (Issue 2012-1) (2012), at 7.

${ }^{18} 1998$ Rome Statute of the International Criminal Court, 2187 UNTS 3.

${ }^{19}$ Prosecutor v Lubanga, 14 March 2012 (not yet published), available at: <http://www.icccpi.int/iccdocs/doc/doc1379838.pdf> [last accessed 12 May 2012].

${ }^{20}$ Agha, 'WTO Dispute Settlement Body developments in 2010', (2011) at <http://www.wto.org/ english/tratop_e/dispu_e/speech_agah_4mar10_e.htm> [last accessed 22 March 2012].
} 
mechanism has given several decisions of far-reaching importance in international economic relations.

Lastly, there has been the dramatic increase in litigation before international human rights courts and tribunals. In 1977 the only such court was the ECtHR (although its work was shared with the European Commission of Human Rights which was merged with the Court in 1998). Its workload has swelled to the point where it now gives well over 1,000 judgments a year. ${ }^{21}$ Moreover, it has been joined as a body which can hear individual claims or petitions by the UN Human Rights Committee, the Inter-American Court and Commission of Human Rights, the African Court of Human and Peoples' Rights and a number of specialist committees which can hear individual petitions under specific human rights agreements such as the 1984 UN Convention against Torture and Other Cruel, Inhuman or Degrading Treatment or Punishment. ${ }^{22}$

\section{Challenges}

The increase in international litigation in one generation has thus been remarkable. What are the challenges associated with it? The answer to that question is likely to vary according to the perspective of the person addressing it. I am conscious that the issues which strike me as most important as a judge are not the same as the ones I would have focussed upon a few years ago as an advocate, and that the list I would have produced as a professor would probably have been even more different. Conscious, therefore, that this is in no sense an exhaustive list, I want to focus on four areas where I believe there are challenges which need to be overcome.

\subsection{The volume of work}

The first issue that I want to consider is the challenge posed by the sheer volume of cases now being brought before some international courts and tribunals. In one sense this is an example of what a British Prime Minister once referred to as "the problems of success". While the fact that more international disputes are being resolved by adjudication and more individuals are able to vindicate their rights in court is a matter for rejoicing, we need to face the fact that it has

\footnotetext{
${ }^{21}$ ECtHR, Overview: 1959-2011 (2012), at 4.

221984 Convention against Torture and Other Cruel, Inhuman or Degrading Treatment or Punishment, 1465 UNTS 85.
} 
also placed a considerable strain on systems designed to deal with far smaller workloads.

The problem is most acute in the field of human rights and, in particular, in the ECtHR based in Strasbourg. The jurisdiction of that court now extends to 47 states with a combined population of over 800 million. ${ }^{23}$ In 2011 the Court gave 1,511 judgments and dealt with 52,188 applications, but its list of pending applications still increased from 139,650 to 151,600, with another 22,600 at an early administrative stage. ${ }^{24}$ It would be presumptuous of me to suggest how the Court-and, perhaps more importantly, the member states of the Council of Europe-should seek to tackle this problem, but anyone can recognise that the burden on the Court has become almost intolerable.

It might be thought that the ICJ, with thirteen cases currently pending, stands at the other extreme, but the comparison is a false one. The ICJ is certainly not pressed to anything like the extent of the ECtHR but, unlike the ECtHR, the ICJ has no power of summary dismissal and none of the cases before the Court could reasonably be described as frivolous. On the contrary, most are cases of considerable importance and complexity which require extensive pleading by the parties and careful deliberation by the Court, whose working methods (described in unusual detail in the Resolution concerning the Internal Judicial Practice of the Court adopted in 1976, when the Court had very few cases) necessarily have to be very thorough. While a backlog of work built up in the late 1990s and early 2000s, a series of internal reforms introduced by the Court, and the addition of new legal assistants, meant that the backlog has now largely been cleared and, at present, the Court is able to keep on top of its case-load while being faithful to the working methods laid down in the 1976 Resolution. Nevertheless, I believe the matter must be kept under constant review. The old maxim that "justice delayed is justice denied" is just as true of international law as of any other legal system, and all international courts need to be able to deal with the cases brought before them in a reasonably expeditious fashion.

\subsection{Jurisdictional limits}

The second challenge to which I want to draw attention is the effect of limits on the jurisdiction of international courts and tribunals. It is one of the best established principles of international law that the jurisdiction of an

\footnotetext{
${ }^{23}$ Council of Europe, Living Together: Combining Diversity and Freedom in $21^{15 t}$-Century Europe: Report of the Group of Eminent Persons of the Council of Europe (2011), at 52.

${ }^{24}$ ECtHR, Analysis of Statistics 2011 (2012), at 4.
} 
international court has to be based upon the consent of the states concerned. The ICJ has stated that principle in the following terms:

... one of the fundamental principles of [the Statute of the Court] is that it cannot decide a dispute between States without the consent of those States to its jurisdiction; and ... the Court therefore has jurisdiction only between States parties to a dispute who not only have access to the Court but also have accepted the jurisdiction of the Court, either in general form or for the individual dispute concerned. ${ }^{25}$

Of course, as the passage quoted recognises, the relevant consent may have been given many years earlier in a bilateral or multilateral treaty and, if that has been done, the respondent state will be bound by that consent however much it might object at the time proceedings are brought against it. Moreover, in the sphere of international criminal law, and within some treaty regimes, the requirement of state consent has been somewhat qualified. The ICTY and ICTR were created by the UN Security Council and exercise jurisdiction over persons, some of whom were high state officials, irrespective of the lack of consent of the states concerned. The Security Council also possesses, and has used, the power to refer cases to the ICC even where the defendants come from states not party to the Rome Statute. Within the treaty regime created by the European Convention on Human Rights, acceptance of the jurisdiction of the ECtHR is now compulsory for parties to the Convention.

Nevertheless, consent remains the normal requirement. That can mean that an international court has jurisdiction over a complaint against one state when an identical complaint, based on the same facts, against another state cannot be heard, because only the first of these states has consented to the jurisdiction of the court concerned. It was for that reason that the ICJ had jurisdiction to rule on the Democratic Republic of the Congo's application against Uganda, ${ }^{26}$ but not on its application, which made essentially the same allegations, against Rwanda. ${ }^{27}$ Uganda (like the Democratic Republic of the Congo) had made a declaration accepting the jurisdiction of the ICJ under Article 36(2) of the

${ }^{25}$ Armed Activities on the Territory of the Congo (New Application: 2002) (Democratic Republic of the Congo v Rwanda), Provisional Measures, Order, ICJ Reports 2002, p. 219, at 241, para. 57.

${ }^{26}$ Armed Activities on the Territory of the Congo (Democratic Republic of the Congo v Uganda), Judgment, ICJ Reports 2005, p. 168.

${ }^{27}$ Armed Activities on the Territory of the Congo (New Application: 2002) (Democratic Republic of the Congo v Rwanda), Jurisdiction and Admissibility, Judgment, ICJ Reports 2006, p. 6. 
Statute of the Court (the so-called "optional clause"), whereas Rwanda had not. ${ }^{28}$ While the number of states accepting the jurisdiction of the Court under the optional clause has increased over the years, at 66 out of a UN membership of 193 it still represents a far smaller percentage of the international community than that which accepted the compulsory jurisdiction of the pre-war Permanent Court of International Justice (42 out of 55 states). Moreover, while three of the five permanent members of the Security Council accepted the compulsory jurisdiction of the Court in the 1960s, only the United Kingdom continues to do so.

To some extent, the deficiencies in the jurisdiction of the ICJ under the optional clause are compensated for by the jurisdiction conferred upon it by the growing number of multilateral conventions which provide for disputes regarding their interpretation or application to be referred to the Court. ${ }^{29}$ But if jurisdiction can be based only upon a clause of this kind, the consequence may be that the Court has jurisdiction only in respect of one aspect of what may be a far broader dispute between the states concerned. For example, in its 2007 judgment in the case brought by Bosnia and Herzegovina against Serbia and Montenegro, ${ }^{30}$ the Court was able to rule only on the issues relating to the Genocide Convention (Article IX of which provided the sole basis of jurisdiction), and could not consider other aspects of the broader dispute between the two countries such as the application of the international law on the use of force or of the Geneva Conventions on international humanitarian law.

One of the challenges for counsel in a case where the only basis for jurisdiction is a treaty dealing with a specific subject is to frame the case in such a way as to bring it within that treaty. An even greater challenge for the Court is to deal effectively with the case before it while remaining faithful to the proper interpretation of the clause which confers jurisdiction and to the fundamental principle of consent as the basis for jurisdiction.

\footnotetext{
${ }^{28}$ I make no comment on what the Court would have decided in the case against Rwanda if it had possessed jurisdiction.

${ }^{29}$ For example, the Convention Against Torture, supra note 22, and most of the conventions on terrorism contain a clause of this kind.

${ }^{30}$ Application of the Convention on the Prevention and Punishment of the Crime of Genocide (Bosnia and Herzegovina $v$ Serbia and Montenegro), Judgment, ICJ Reports 2007, p. 43, at 101-2, para. 141.
} 


\subsection{Diversity}

The third challenge I want to discuss is that caused by diversity within the "system" of international courts and tribunals. International courts and tribunals inevitably bring together judges and lawyers of different nationalities and backgrounds. That is, of course, both necessary and desirable. A global court must comprise judges from across the globe and not from just one region or legal tradition. It is for that reason that the Statute of the International Court of Justice precludes two persons of the same nationality serving as judges at the same time ${ }^{31}$ and provides that-

At every election, the electors shall bear in mind not only that the persons to be elected should individually possess the qualifications required, but also that in the body as a whole the representation of the main forms of civilization and of the principal legal systems of the world should be assured. ${ }^{32}$

The comparable provision for the ICC is even more elaborate. ${ }^{33}$ Moreover, international judges tend to come from a wider range of professional backgrounds than their counterparts in national courts. While judges in England, for example, are almost invariably former barristers or solicitors, the current composition of the International Court of Justice contains a large number of former diplomats and foreign ministry legal advisers, as well as professors of international law.

This diversity in the international judiciary is a strength for international courts. Yet it is important not to underestimate the far greater difficulty of achieving a unified approach to procedural questions (where differences between legal systems are frequently far more marked than in substantive law, and where underlying assumptions tend to be taken for granted) when the members of the bench do not have the advantage of many years of common experience as counsel or as career judges that is typical in most national courts. For example, anyone trained in common law tends to take for granted certain basic propositions about the burden and standard of proof but those assumptions are by no means shared across legal systems, or by judges whose legal experience has been rooted more in advisory work in a foreign

\footnotetext{
${ }^{31} 1945$ Statute of the International Court of Justice, 33 UNTS 993, Article 3(1). This provision does not apply to judges ad hoc and it is often the case that one or even both such judges are of the same nationality as members of the regular Court.

${ }^{32}$ Ibid., Article 9.

${ }^{33}$ Rome Statute, supra note 18 , Article 38.
} 
ministry, or in the United Nations, rather than in advocacy. They often have different (and equally valid) assumptions about such matters. Even between lawyers with similar experience but in different systems there can be marked differences. In the early days of the international criminal tribunals, difficulties arose even between lawyers from the very similar United States and English systems because the latter considered that they were prohibited from preparing witnesses for cross-examination, while the former believed they were required to do just that. The challenges provided by this kind of diversity are manageable, and are more than outweighed by the strengths which it produces, but it is a mistake to pretend that such challenges do not exist.

There is another type of diversity, however, which has the potential to be far more problematic; that is, the diversity of courts and tribunals themselves. The same issue can-and not infrequently does-now come before more than one international court. To date that has tended to be in different factual contexts; that is to say two different courts have had to consider the same question of international law but have done so in relation to different sets of facts. It is, however, perfectly possible for the same set of facts to generate proceedings in more than one international jurisdiction. Let us take what is, at least so far, a hypothetical example. The ICC issues an arrest warrant for an official (X) of a state not party to the Statute of the ICC (state A). That warrant is executed by a state (state B) which is a party to the Statute and in which X happens to be present. X contests the legality of his arrest before the ICC, claiming (with the support of state A) that he is entitled to immunity. He also brings proceedings against state $\mathrm{B}$ before a regional human rights court to challenge the process by which he was surrendered to the ICC, a challenge which also involves the issue of his claim to immunity. In addition, state $\mathrm{A}$ brings proceedings against state B in the International Court of Justice, claiming that state B's decision to disregard the immunity to which state $A$ considers $X$ was entitled amounted to a violation of an obligation owed by state $B$ to state $A$. In such circumstances, all three courts would have to consider the question of immunity and might well come to different conclusions. In the absence of a hierarchy in which one court is given the last word, so it is said, there is scope for something approaching anarchy.

That is the nightmare of those who see the multiplication of international courts and tribunals bringing about a fragmentation of the international legal system. There is, of course, much more to the debate about fragmentation than just the possibility of different courts reaching different conclusions on the same question. The International Law Commission has undertaken a study 
of the subject ${ }^{34}$ which has attracted much scholarly comment. ${ }^{35}$ This is not the place for me to enter into all the aspects of that debate. Suffice it to say that, at least as far as the multiplication of international courts and tribunals is concerned, I believe that the dangers of fragmentation are greatly exaggerated.

It is true that there was a notable difference of view in the International Court of Justice and the Appeals Chamber of the ICTY regarding the circumstances in which a state may be held responsible for the acts of non-state actors with which it is associated. In its judgment in Prosecutor $v$ Tadic ${ }^{36}$ in 1999, the Appeals Chamber expressly declined to accept the principles laid down by the ICJ thirteen years earlier in Military and Paramilitary Activities in and Against Nicaragua (Nicaragua $v$ United States of America). ${ }^{37}$ The matter came before the ICJ again in Application of the Convention on the Prevention and Punishment of the Crime of Genocide (Bosnia and Herzegovina $v$ Serbia and Montenegro), ${ }^{38}$ when the ICJ reaffirmed its earlier approach in Nicaragua notwithstanding the decision in Tadić. Yet the attention paid to this difference between two adjudicative bodies tends to ignore the fact that the ICJ in its 2007 judgment, far from disregarding Tadić, followed the findings of fact made by the ICTY in that case. Moreover, the difference over the legal question of responsibility in this saga is almost the only example of its kind. Other instances in which two courts have apparently differed, such as the refusal of the ECtHR in Loizidou v. Turkey ${ }^{39}$ to apply to declarations regarding its own jurisdiction principles developed by the ICJ in cases concerning declarations under Article 36(2) of the Statute of the ICJ, turn out to be cases not of disagreement but of one court finding that the reasoning of another should not be transplanted to the different context of the issue which it had to decide. In Loizidou, the ECtHR did not say (as the ICTY did in Tadic) that the ICJ was wrong; rather it distinguished the reasoning of the ICJ on the ground that the acceptance of the jurisdiction of the ECtHR in the context of a treaty designed to protect the rights of individuals rather than states was to be approached differently from the acceptance of the jurisdiction of the ICJ in inter-state proceedings.

\footnotetext{
${ }^{34}$ See 'Conclusions of the work of the Study Group on the Fragmentation of International Law: Difficulties arising from the Diversification and Expansion of International Law', forthcoming (2006) II(ii) ILC Ybk.

${ }^{35}$ For a comparatively recent and very perceptive example, see Simma, 'Universality of International Law from the Perspective of a Practitioner', (2009) 20(2) EJIL 265.

${ }^{36}$ Case No IT-94-1-T, 1999, at 40-62, paras. 99-145.

${ }^{37}$ Judgment, ICJ Reports 1986, p. 14.

${ }^{38}$ Judgment, ICJ Reports 2007, p. 43, at 209-11, paras. 403-7.

${ }^{39}$ Loizidou v Turkey, Preliminary Objections, Judgment of 23 March 1995, [1995] ECHR (Ser A.), paras. 82-6.
} 
While such fragmentation is a danger against which international lawyers must be on their guard, it is a danger which can be met and is very far from being the present reality which some commentators have suggested.

\subsection{Compliance}

The last challenge that I wish to mention is that of securing compliance with the judgments of international courts and tribunals. The importance of ensuring that the judgment of a court or tribunal is actually carried out is obvious. A judgment which is ignored by the losing party is not only ineffective, it may serve to discredit the court which gave it and, indeed, the entire international legal system. It is, however, well known that international courts and tribunals have at their disposal little if any of the apparatus with which national courts can compel the implementation of their decisions. While Article 94(2) of the UN Charter gives the Security Council power to take measures against a recalcitrant state to give effect to a decision of the ICJ, that power has never been used. ${ }^{40}$ The difficulties in securing the surrender of those indicted for the most serious international crimes which were faced in the past by the ICTY and are faced today by the ICC have long been a matter of notoriety. Is this the challenge which is going to overwhelm the international system of adjudication? That is an important question and one which requires a far more detailed study than is possible here. The risk is undoubtedly a real one. Nevertheless, there are grounds for at least cautious optimism.

First, the overall picture is far less gloomy than might be imagined. Notwithstanding the lack of any effective means of compulsion, judgments of the ICJ are generally respected by the parties and the record of compliance is good. ${ }^{41}$ The same has been true of most of the other courts and tribunals in the international legal system. The decisions of the WTO dispute settlement mechanism, the judgments of ITLOS, the awards of investment arbitration tribunals and of the various inter-state arbitration tribunals have in recent years attracted a good record of compliance. Perhaps more surprisingly, given the extent to which they intrude upon what many national authorities still regard

\footnotetext{
${ }^{40}$ The Security Council has, however, with the consent of all parties established monitoring missions to supervise compliance with certain judgments of the Court. See, e.g., Report of the UN Secretary-General, UN Doc. S/1994/512 (1994) and SC Res 915, 4 May 1994 regarding the work of such a mission in supervising compliance with the judgment of the Court in Territorial Dispute (Libyan Arab Jamahiriya/Chad), Judgment, ICJ Reports 1994, p. 6.

${ }^{41}$ For a detailed study, see Schulte, Compliance with Decisions of the International Court of Justice (OUP, 2004).
} 
as matters of domestic concern and the sheer number of cases, the picture is also quite positive with regard to human rights judgments. Problems there tend to stem from the inability of some governments to come to terms with what is required to comply, for example, with a requirement to avoid lengthy delays in judicial processes, rather than acts of outright defiance.

Secondly, it should come as no surprise that it is international criminal law which has, in recent years, given rise to the largest number of refusals to comply with the orders of international courts and tribunals. It is this part of international law which confronts most directly the sovereignty of states and challenges often deep-seated national feelings. It is also this part of international law where the jurisdiction of international courts and tribunals has moved furthest from a basis in the consent of the states concerned. Moreover, it is in the sphere of criminal law that national courts most often have to call upon the full resources of their states to compel compliance. Yet even here, the challenge can be met if there is the will to do so. Despite initial pessimism, the ICTY eventually secured the presence of all the defendants it had indicted, including the former head of state of the FRY, the President, Prime Minister and Commander-in-Chief of Republika Srpska and a number of prominent figures from all sides in the conflict. At the time of writing, the Special Court for Sierra Leone was about to give judgment in the trial of Charles Taylor, former President of Liberia, and the former President of Côte d'Ivoire was in custody awaiting trial at the ICC. One lesson is that ensuring compliance in this context may well be a long game.

\section{Conclusions}

The growth in importance of international courts and tribunals in the last thirty or so years has contributed much to international society. The record of international disputes peacefully resolved by adjudication which, only a few decades ago, might have led to war is an impressive one. Even where war was not a possibility (or at least a likelihood), the contribution has been important. The changes in the law of the sea in the 1970s could have led to a maritime version of the scramble for Africa of a century earlier had it not been for a series of judicial and arbitral decisions on delimitation. The WTO, with its dispute settlement mechanism, has helped so far to prevent a slide into protectionism of the kind which followed the last great financial crisis in the 1930s. International criminal courts and tribunals have made the prospect of a war criminal or génocidaire being called to account for their actions a reality, even if the full 
implications may not be realised for years to come. Human rights courts and tribunals have played a major part in bringing about a substantial improvement in respect for human rights in much of the world.

Nothing in the present paper is intended to minimise the importance or the value of these developments. But it is important to see them in perspective. That requires consideration of the challenges facing the international adjudicative system. In this paper, I have tried to set out a few of those challenges. None of them is insuperable but they are nonetheless real. 